\title{
RUSSIAN FOOD EMBARGO: MINOR LOSSES IN WESTERN COUNTRIES ${ }^{1}$ V.Uzun, D.Loginova
}

Most of the countries counter-sanctioned by Russia have seen no decline in food exports, increasing them to other countries to compensate for losses in the Russian market. Only a few countries have experienced a decline in exports due to the Russian food embargo, namely Norway (a total decline of $11.3 \%$, of which the Russian market accounts for 10.1\%), Finland (respectively $24.5 \%$ and $20.9 \%)$, Lithuania (20.7\% and 20.6\%), Latvia (21.5\% and $11.5 \%$ ), Estonia (22.8\% and $12.2 \%)$, Poland (4.8\% and $4.6 \%$ ).

There is an established opinion in Russia that the countries that support sanctions against Russia have sustained considerable losses due to the Russian food embargo. There are few publications that prove it wrong ${ }^{2}$. Mass media and economic literature generally assess the effect of the food embargo using data showing the decline in import volumes from these countries to Russia ${ }^{3}$. However, the respective losses should be assessed given both the decline in exports to Russia and the changes in exports to the markets of other countries.

The Table (see the Attachment hereto) shows that food exports to Russia from the counter-sanctioned countries fell sharply (by $\$ 12.4 \mathrm{bn}$ ) in 2015, as compared to 2013 . The deepest decline was seen in Norway $(\$ 1134 \mathrm{~m})$, USA $(\$ 914 \mathrm{~m})$, EU member countries as a whole $(\$ 9634 \mathrm{~m})$, including Germany $(\$ 1162 \mathrm{~m})$, Lithuania $(\$ 1284 \mathrm{~m})$, The Netherlands $(\$ 1071 \mathrm{~m})$, Poland $(\$ 1027 \mathrm{~m})$.

The overwhelming majority of these countries have seen exports decline not only to Russia but also to other countries over the same period. The biggest losses $(\$ 61.9 \mathrm{bn})$ have been sustained by EU member countries $(\$ 14 \mathrm{bn}$ by The Netherlands, more than $\$ 10$ bn by France and Germany each, $\$ 8 b n$ by Belgium). In fact, these countries sustained inconsiderable losses in the Russian market amid the overall decline in exports from these countries. For example, exports in Slovakia dropped $28.9 \%$, with losses in the Russian market being as little as $0.8 \%$. Exports in France fell $15.6 \%$, losing $0.9 \%$ in the Russian market.

At the same time, some countries sustained major losses in the Russian market. For example, Norway lost $11.3 \%$ in the global market, of which the Russian market accounted for $10.1 \%$. Finland saw its entire food exports fall

1 This paper was originally published in Online Monitoring of Russia's Economic Outlook No.14(32).

2 Shagaida N., Uzun V. Food embargo and choice of priorities /Voprosy Economiki. 2016. No. 7, pp. 93-105.

3 Western countries sustain $\$ 8.6 \mathrm{bn}$ in losses due to food embargo / https:// rg.ru/2016/08/02/poteri-stran-zapada-ot-prodembargo-sostavili-86-milliarda-dollarov.html; The Baltic states conceal real losses of "the War of Sanctions" /http://newvhttp://www.rubaltic.ru/article/ekonomika-i-biznes/200116-sanktsii/z.ru/info/80283.html ;Losses in the war of sanctions against Russia: Brussels count losses / http://newvz.ru/info/80283.html ;Loss count in the war of sanctions. Russia's Ministry of Economic Development have assessed losses sustained due to the food embargo / http://www.newizv.ru/economics/2016-08-02/243960-vsankcionnoj-vojne-podschitali-poteri.html 
$24.5 \%$, of which the Russian market accounted for $20.9 \%$, Lithuania (respectively $20.7 \%$ and $20.6 \%)$, Latvia (21.5\% and $11.5 \%)$, Estonia $(22.8 \%$ and $12.2 \%)$, Poland (4.8\% and $4.6 \%)$.

The initiators of sanctions against Russia, namely the United States, Great Britain, Canada, Germany, France, have sustained minor specific losses from the Russian food embargo. Russia's neighbour countries with whom Russia had well established food trade were hurt the most by the counter-sanctions.

An emphasis should be placed on the fact that food prices have recently been on the slide in the global market. And to obtain a more objective assessment, further study of the effects of the embargo is needed using physical values of exports and imports ${ }^{1}$.

The EU increased exports (in physical terms) of most types of products in 2015, that is, EU member countries found new markets for the products sanctioned by Russia. And, in terms of value, there was no decline in exports from the EU. Instead, they increased to 482.5 bn euro in 2015, as compared to $455.1 \mathrm{bn}$ euro in 2013. The decline in value of exports (in USD terms) was driven by the euro-dollar exchange rate (1.11 in 2015 compared to 1.33 in 2013). There is a prevailing view in Russian and European mass media that the agrifood market is facing problems due to the Russian embargo, although the key culprit is the national currency devaluation, both in Russia and the EU.

Meat and meat products, milk and dairy products, vegetables and fruits were the principal items of exports from EU member countries to Russia. In 2013 , these products accounted, respectively, for $19.8 \%, 14.2 \%, 23.4 \%$ and $32.5 \%$ of EU member countries' exports outside the EU. Given the exports within the EU, Russia's share was much smaller (respectively 3.7\%, 3.4\%, 3.7\% and 5.1\%). Table 1 shows an overall response of EU markets to the Russian embargo on food imports.

Table 1

EXPORTS OF SELECTED PRODUCTS FROM EU TO RUSSIA AND TO OTHER COUNTRIES

\begin{tabular}{|c|c|c|c|c|c|c|c|c|}
\hline & \multicolumn{2}{|c|}{$\begin{array}{c}\text { Meat and meat } \\
\text { products }\end{array}$} & \multicolumn{2}{|c|}{$\begin{array}{c}\text { Milk and dairy } \\
\text { products }\end{array}$} & \multicolumn{2}{|c|}{ Vegetables } & \multicolumn{2}{|c|}{ Fruits } \\
\hline & $\begin{array}{l}\frac{\pi}{N} \\
\stackrel{n}{\partial} \\
\simeq\end{array}$ & 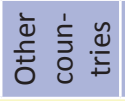 & $\underset{\frac{\pi}{n}}{\stackrel{0}{D}}$ & 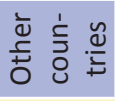 & $\begin{array}{l}\frac{\pi}{\sqrt{n}} \\
\stackrel{n}{\partial} \\
\propto\end{array}$ & 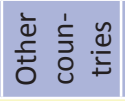 & 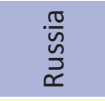 & 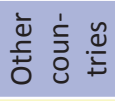 \\
\hline \multicolumn{9}{|c|}{ thousand tonnes } \\
\hline 2013 & 852 & 16985 & 441 & 24367 & 948 & 25827 & 1614 & 20861 \\
\hline 2014 & 165 & 18348 & 273 & 25570 & 661 & 26307 & 1074 & 22254 \\
\hline 2015 & 10 & 19065 & 49 & 27230 & 81 & 26885 & 104 & 24108 \\
\hline $\begin{array}{l}\text { Changes } \\
(+,-) \text { in } 2015 \\
\text { as compared } \\
\text { to } 2013\end{array}$ & -842 & 2080 & -392 & 2863 & -868 & 1057 & -1510 & 3246 \\
\hline \multicolumn{9}{|l|}{ million euro } \\
\hline 2013 & 1608 & 41501 & 1462 & 41918 & 769 & 20173 & 1258 & 24477 \\
\hline 2014 & 280 & 42866 & 936 & 44357 & 505 & 19484 & 802 & 24826 \\
\hline 2015 & 14 & 43691 & 211 & 42034 & 68 & 21664 & 96 & 27621 \\
\hline $\begin{array}{l}\text { Changes } \\
(+,-) \text { in } 2015 \\
\text { as compared } \\
\text { to } 2013\end{array}$ & -1594 & 2190 & -1251 & 116 & -700 & 1490 & -1162 & 4305 \\
\hline
\end{tabular}

Source: Eurostat.

1 Below is analysis that was made using the Eurostat's data, because the Comtrade database provides no data on sales in physical volume. 
The decline in exports to Russia was offset by growth in exports to other countries. In terms of value, extra revenues in other countries failed to compensate for the losses in Russia despite growth in volumes of milk exports alone, because exports to Russia used to include more expensive types of food products (cheese, etc.).

The foregoing provide the picture in the $\mathrm{EU}$ as a whole. The picture by country differs largely from the EU average. Almost all the major exporters of meat products found a replacement for the Russian market, and not only did they compensate for the loss, but also their exports were increased (Table 2).

For example, Poland cut its exports of meat products to Russia by 77,000 tonnes as its exports to other countries were increased by 373,000 tonnes. The sole exception is France that failed to compensate for cutbacks on supplies to Russia with sales in other markets. Germany, Denmark, Belgium saw their revenues from meat exports drop considerably.

Table 2

CHANGES IN VOLUME AND VALUE OF EXPORTS OF MEAT AND MEAT PRODUCTS FROM EU

\begin{tabular}{|c|c|c|c|c|c|c|}
\hline & \multicolumn{6}{|c|}{ Growth (+) / decline in exports in 2015 as compared to 2013.} \\
\hline & \multicolumn{2}{|c|}{ To Russia } & \multicolumn{2}{|c|}{ To other countries } & \multicolumn{2}{|c|}{ Total } \\
\hline & $\begin{array}{l}\text { thousand } \\
\text { tonnes }\end{array}$ & million euro & $\begin{array}{l}\text { thousand } \\
\text { tonnes }\end{array}$ & million euro & $\begin{array}{l}\text { thousand } \\
\text { tonnes }\end{array}$ & million euro \\
\hline EU-28 & -841.69 & -1594.09 & 2080.21 & 2189.50 & 1238.52 & 595.41 \\
\hline Germany & -184.91 & -333.39 & 284.22 & -159.93 & 99.31 & -493.32 \\
\hline Denmark & -134.63 & -284.45 & 125.53 & -141.03 & -9.11 & -425.48 \\
\hline France & -86.94 & -123.92 & -16.67 & -139.38 & -103.62 & -263.30 \\
\hline Poland & -77.73 & -159.57 & 373.25 & 689.68 & 295.52 & 530.11 \\
\hline $\begin{array}{l}\text { The } \\
\text { Netherlands }\end{array}$ & -74.06 & -138.86 & 286.52 & 245.92 & 212.45 & 107.06 \\
\hline Spain & -53.64 & -116.02 & 526.05 & 837.12 & 472.41 & 721.11 \\
\hline Belgium & -44.62 & -69.68 & 136.41 & -55.26 & 91.78 & -124.93 \\
\hline Hungary & -36.08 & -79.99 & 61.06 & 77.18 & 24.97 & -2.80 \\
\hline Italy & -35.51 & -56.93 & 43.91 & 245.27 & 8.40 & 188.34 \\
\hline Ireland & -29.49 & -69.25 & 127.30 & 405.75 & 97.81 & 336.50 \\
\hline Lithuania & -27.25 & -64.13 & 38.66 & 61.43 & 11.41 & -2.70 \\
\hline Austria & -26.86 & -48.96 & 57.77 & 22.44 & 30.91 & -26.52 \\
\hline
\end{tabular}

Source: Eurostat.

The picture for dairy products is somewhat different. Expensive products ceased to be exported to Russia due to the Russian embargo. It was not always possible to export expensive products to other countries. The export pattern underwent some changes and almost all the exporters saw their revenues decline, although sales volumes increased (Table 3).

Lithuania sustained financial losses in the vegetable, although it managed to compensate for cutbacks in exports to Russia (in terms of volume) by increasing exports to other countries (Table 4).

Poland was the sole country whose fruits exports were hurt by the Russian embargo. Exports to Russia were cut by 782,000 tonnes, which was partially offset by increasing exports to other countries (433,000 tonnes). 


\section{CHANGES IN VOLUME AND VALUE OF EXPORTS OF MILK AND DAIRY PRODUCTS FROM EU (FEACN 04)}

\begin{tabular}{|c|c|c|c|c|c|c|}
\hline & \multicolumn{6}{|c|}{ Growth (+) / decline in exports in 2015 as compared to 2013.} \\
\hline & \multicolumn{2}{|c|}{ To Russia } & \multicolumn{2}{|c|}{ To other countries } & \multicolumn{2}{|c|}{ Total } \\
\hline & $\begin{array}{l}\text { thousand } \\
\text { tonnes }\end{array}$ & million euro & $\begin{array}{c}\text { thousand } \\
\text { tonnes }\end{array}$ & million euro & $\begin{array}{c}\text { thousand } \\
\text { tonnes }\end{array}$ & million euro \\
\hline EU-28 & -392.15 & -1250.83 & 2863.30 & 115.74 & 2471.15 & -1135.09 \\
\hline Finland & -86.75 & -252.18 & 73.27 & 111.97 & -13.48 & -140.21 \\
\hline $\begin{array}{l}\text { The } \\
\text { Netherlands }\end{array}$ & -63.58 & -225.97 & 1042.30 & -275.33 & 978.71 & -501.30 \\
\hline Lithuania & -47.19 & -152.69 & 47.17 & -27.20 & -0.02 & -179.89 \\
\hline Poland & -45.86 & -139.57 & 321.55 & 95.95 & 275.69 & -43.62 \\
\hline Germany & -45.29 & -153.49 & 437.41 & -482.94 & 392.11 & -636.43 \\
\hline France & -27.73 & -83.63 & 166.52 & 56.05 & 138.79 & -27.58 \\
\hline Denmark & -21.44 & -77.86 & 88.81 & 117.11 & 67.37 & 39.25 \\
\hline Estonia & -20.98 & -49.24 & -11.49 & -11.66 & -32.48 & -60.90 \\
\hline
\end{tabular}

Source: Eurostat.

Table 4

\section{CHANGES IN VOLUME AND VALUE OF EXPORTS OF VEGETABLES FROM EU} (FEACN 07)

\begin{tabular}{|c|c|c|c|c|c|c|}
\hline & \multicolumn{6}{|c|}{ Growth (+) / decline in exports in 2015 as compared to 2013.} \\
\hline & \multicolumn{2}{|c|}{ To Russia } & \multicolumn{2}{|c|}{ To other countries } & \multicolumn{2}{|c|}{ Total } \\
\hline & $\begin{array}{c}\text { thousand } \\
\text { tonnes }\end{array}$ & million euro & $\begin{array}{c}\text { thousand } \\
\text { tonnes }\end{array}$ & million euro & $\begin{array}{c}\text { thousand } \\
\text { tonnes }\end{array}$ & million euro \\
\hline EU-28 & -867.73 & -700.36 & 1057.35 & 1490.39 & 189.63 & 790.02 \\
\hline Poland & -297.27 & -172.02 & 234.38 & 178.90 & -62.89 & 6.88 \\
\hline Lithuania & -264.45 & -323.60 & 470.75 & 120.73 & 206.30 & -202.88 \\
\hline $\begin{array}{l}\text { The } \\
\text { Netherlands }\end{array}$ & -133.76 & -48.89 & -362.96 & 414.65 & -496.72 & 365.76 \\
\hline Spain & -69.50 & -72.00 & 567.39 & 618.47 & 497.89 & 546.48 \\
\hline Belgium & -47.89 & -40.24 & 258.95 & 224.20 & 211.06 & 183.96 \\
\hline
\end{tabular}

Source: Eurostat.

Table 5

\section{CHANGES IN VOLUME AND VALUE OF EXPORTS OF FRUITS FROM EU (FEACN 8)}

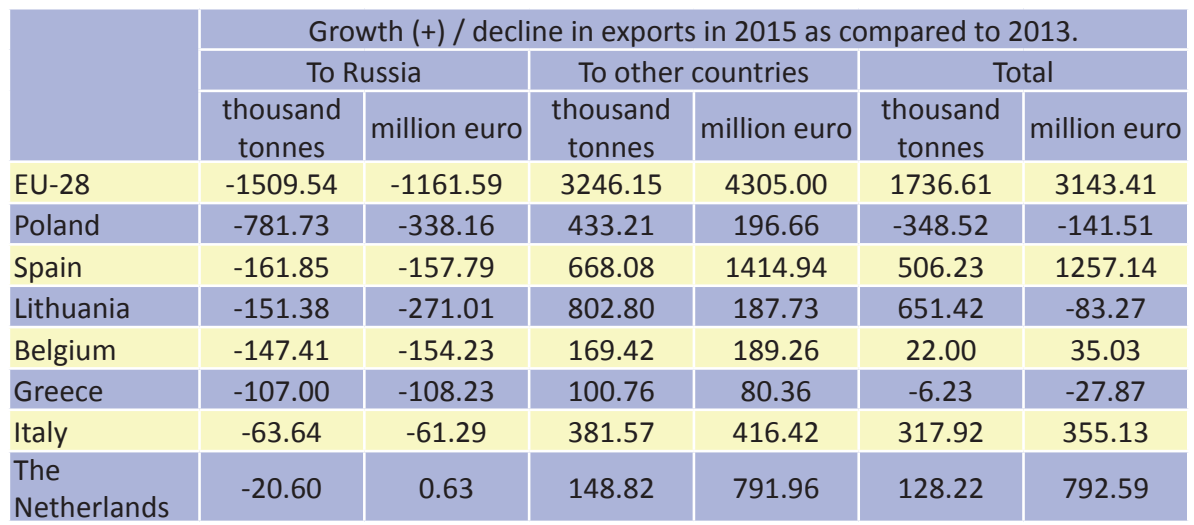

Source: Eurostat.

There were isolated instances where the decline in imports to Russia caused a real decline in volume and value of exports from the counter-sanctioned countries, however, the economic loss was insignificant. Hence the Russian ban on exports of food staples has to date failed to inflict considerable damages to exporters in these countries. 


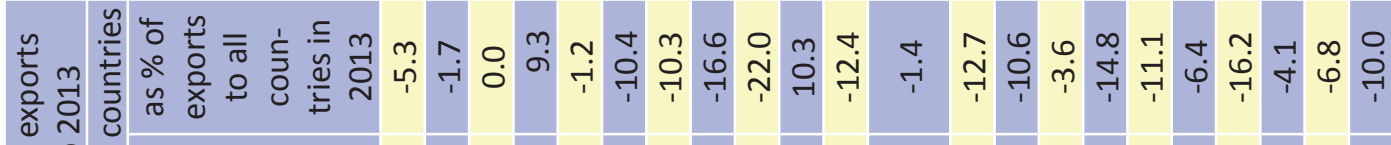

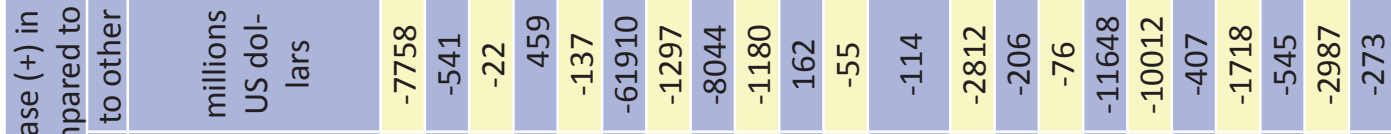
䓈

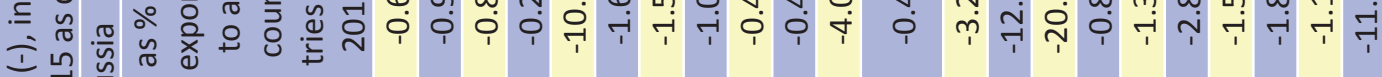

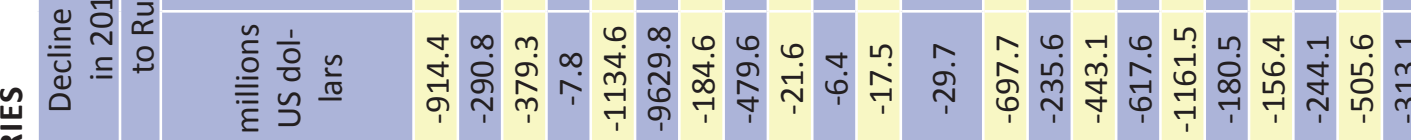

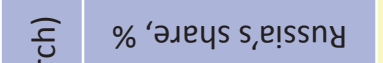

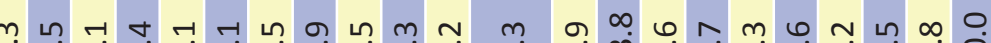

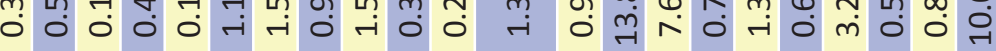

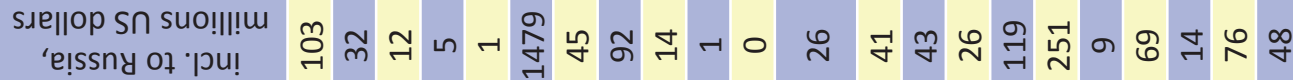
slellop sก $\infty \infty_{\infty} \infty \quad \hat{m}$

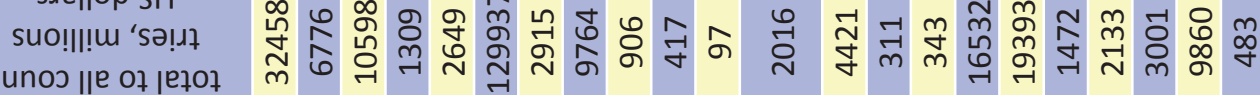

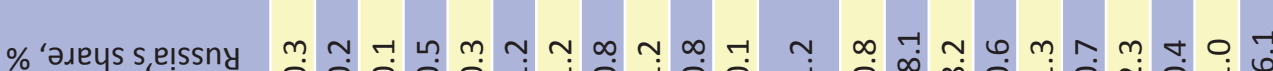

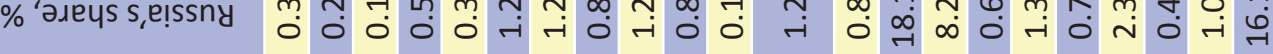

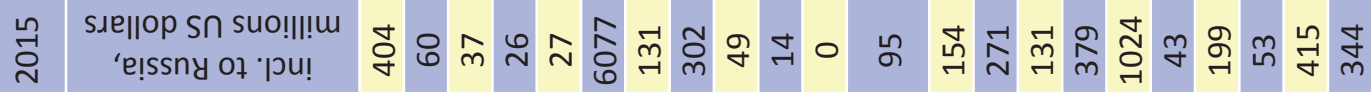

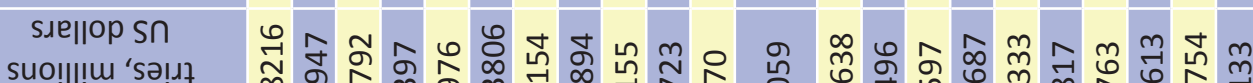

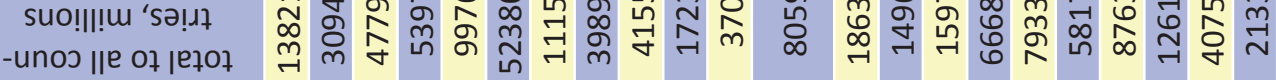

\% כ.

\% 'əueus s,e!ssny

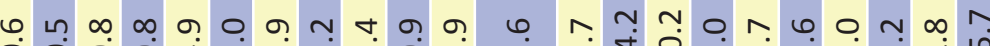

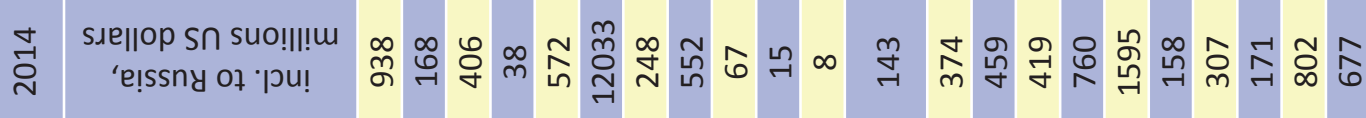
Sue|lop Sn

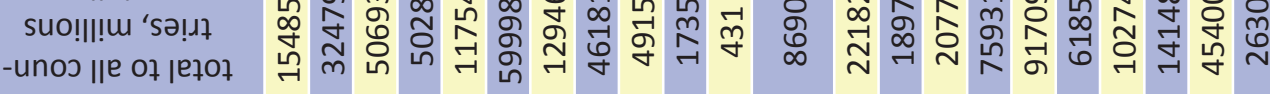

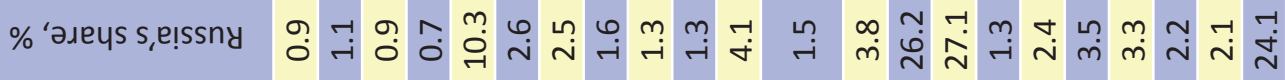

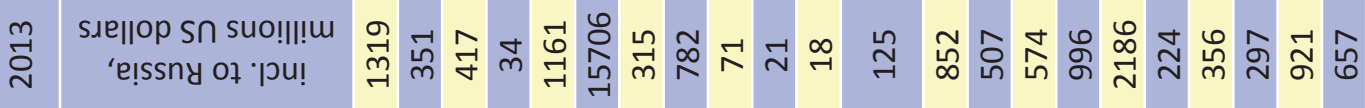

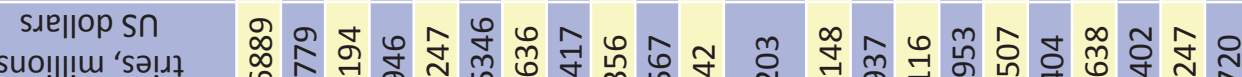

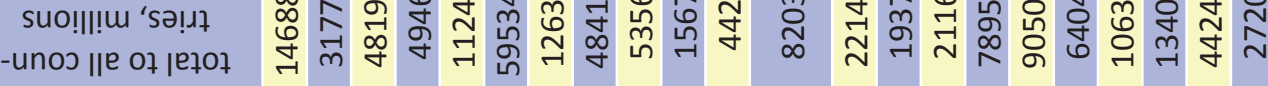




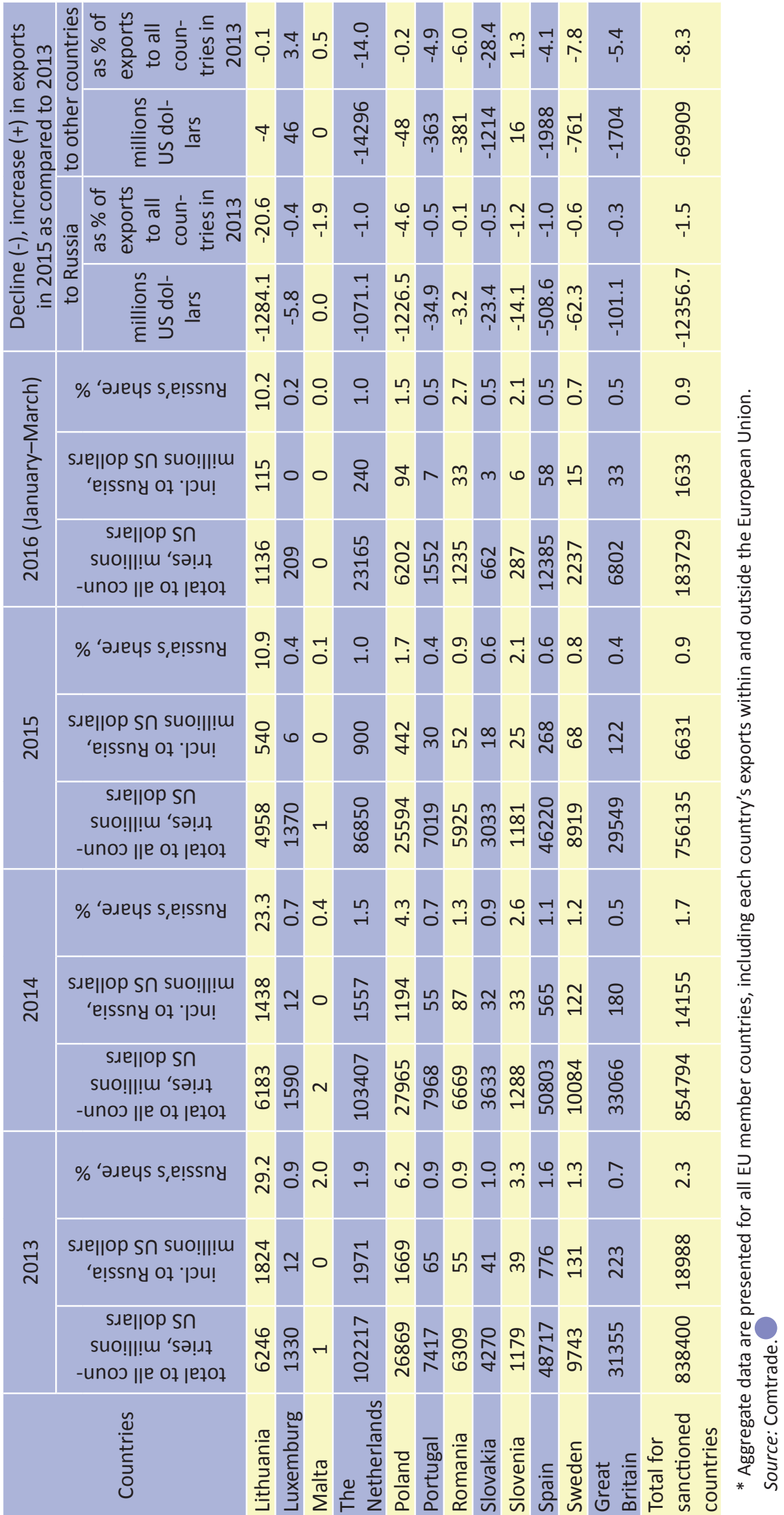

